\title{
IMPROVED PROSPECTS FOR THE DOMESTICATION OF Acacia saligna IN REGION DE COQUIMBO, CHILE
}

\author{
M.W. McDonald', R. Mazanec'2, J.R. Bartle ${ }^{2}$ and B.R. Maslin ${ }^{2}$
}

\section{SUMMARY}

Acacia saligna (Labill.) H. Wendl., a nitrogen-fixing shrub or small tree endemic to the south west of Western Australia, is being cultivated for site remediation and stock fodder in Region de Coquimbo of Chile. The paper makes a review of the work which has the potential to improve domestication outcomes involving this species. A recent study has recognised that $A$. saligna comprises five subspecies that differ in subtle morphological traits and have natural distributions that largely occupy different bioregions. The subspecies show differences in economically important traits including climate profiles, habit, biomass potential, coppicing ability and root suckering propensity. Preliminary results from research trials in Western Australia have implications for the domestication potential of these taxa as short-rotation coppice crops. Of the five subspecies only one currently is being widely cultivated in Region de Coquimbo.

Palabras claves: Acacia saligna, domesticación

\section{RESUMEN}

Acacia saligna (Labill.) H. Wendl. Es un arbusto o pequeño árbol, fijador de nitrógeno, nativo y endémico del sur oeste de Western Australia. Es cultivado en la Región de Coquimbo, Chile, para forraje y mejoramiento de suelos. Este artículo revisa el trabajo necesario para mejorar los logros en la domesticación de esta especie. Un estudio reciente ha reconocido que A saligna comprende cinco subespecies que difieren sutilmente en rasgos morfológicos y tienen una distribución natural que ocupa marcadamente diferentes subregiones. Las subespecies muestran diferencias en aspectos que son económicamente importantes en materia de clima, hábitos, biomasa potencial, habilidad de rebrotar desde cepas y tendencia a emitir brotes de raices. Resultados preliminares en ensayos en Western Australia tienen relación con el potencial de domesticación de esta especie como cultivos de corta rotación en monte bajo. De las cinco subespecies, sólo una está siendo ampliamente empleada en la Región de Coquimbo.

Palabras claves: Acacia saligna, domestication

\footnotetext{
'Ensis, CSIRO Centre for Environment and Life Sciences, PO Box 5. Wembley, WA 6913; email:maurice.mcdonald@ensisjv.com

${ }^{2}$ Department of Environment and Conservation, Locked Bag 104, Bentley Delivery Centre. Western Australia, 6983. Australia; email: john.bartle@dec.wa.gov.au
} 


\section{INTRODUCTION}

Over the past decade, there has been considerable interest in the domestication of Acacia saligna (Labill.) H. Wendl. in dryland parts of Chile. Endemic to the south west Western Australia, this shrub or small tree is grown for site remediation and as a source of fodder for stock in Región de Coquimbo (approx. 30-32 S). Approximately 12,000 ha have been established, and its performance to date has created interest in its potential as a source of woody biomass for bioenergy production and other industrial-scale uses such as its seeds as a source of feedstock for fish farming. The increasing use of this species as a sustainable source of biomass in a $100-250 \mathrm{~mm}$ rainfall region is due to its ease of establishment, relatively fast growth and robust coppicing ability. Further domestication of $A$. saligna in Region de Coquimbo has been given high a priority by local Government authorities such as INFOR (Chilean Institute of Forestry) and CONAF (The National Forest Corporation).

A recent study of the natural genetic resources of this species has revealed that morphological variation in this species has a taxonomic basis (McDonald and Maslin in prep.). This study will have important implications for future domestication research on $A$. saligna, as five subspecies will be formally recognised, viz. subsp. lindleyi, subsp. pruinescens, subsp. saligna, subsp. stolonifera and subsp. "Cantabilling" (manuscript names). These taxa demonstrate subtle, variable and temporal morphological differences, and their distributions largely show a geographic replacement pattern across a number of natural bioregions.

The Revegetation Systems Unit of the Department of Environment and Conservation in Western Australia have established numerous trials assessing the potential of these taxa as short-rotation coppice crops for biomass production, to help remediate dryland salinity in the cropping area of south west Western Australia (Hobbs et al. 2006). This work will significantly refine the domestication potential of these subspecies. A brief summary of these activities are presented here. It will be particularly relevant for domestication efforts of this species in Chile as only one of the five subspecies is currently being cultivated in Region de Coquimbo.

\section{THE REVISED GENETIC RESOURCES OF Acacia saligna}

As noted by Maslin and Mc Donald (2004) differences in growth form, biomass production, suckering propensity and fodder value are evident among the newly recognized subspecies. Preliminary results based on field trials and findings from a genetic study have validated the recognition of the five subspecies (ref for field trials; George et al. 2006). To provide background, a brief outline of the five subspecies is given below.

\section{Natural Distribution and Habitat}

All five subspecies of $A$. saligna are endemic to southwest Western Australia, and occur in a winter rainfall zone, across a wide rainfall gradient and in a number of bioregions (Fig. 1). These regions range from tall open forests in coastal and subcoastal areas of the $1000-1200 \mathrm{~mm}$ rainfall zone, to as far inland as the $200-250$ rainfall isohyet where semiarid shrublands predominate. The dry season in this region extends for $6-8$ months of the year. Climate profiles for the five subspecies, based on data from their natural distribution, 
are shown in Table 1. The taxa have distributions that often comprise localised populations that are usually restricted to depositional sites throughout their natural distributions. They tend to favour sites where soil water is supplemented by run-on events from rainfall.

Table 1

CLIMATE PROFILES FOR THE SUBSPECIES BASED ON DATA FROM THEIR NATURAL DISTRIBUTIONS

\begin{tabular}{|l|c|c|c|c|c|c|}
\hline \multicolumn{1}{|c|}{ Taxon } & $\begin{array}{c}\text { Altitudinal } \\
\text { range }(\mathbf{m})\end{array}$ & $\begin{array}{c}\text { Mean max. } \\
\text { hottest month }\end{array}$ & $\begin{array}{c}\text { Mean min. } \\
\text { coldest month }\end{array}$ & $\begin{array}{c}\text { Lowest temp. } \\
\text { recorded }\end{array}$ & $\begin{array}{c}\text { Mean annual } \\
\text { temp. }\end{array}$ & $\begin{array}{c}\text { Mean annual } \\
\text { rainfall (mm) }\end{array}$ \\
\hline lindleyi & $100-350$ & $28-39^{\circ} \mathrm{C}$ & $5-9^{\circ} \mathrm{C}$ & $-5^{\circ} \mathrm{C}$ & $15-21^{\circ} \mathrm{C}$ & $250-650$ \\
\hline pruinescens & $80-420$ & $26-30^{\circ} \mathrm{C}$ & $4-9^{\circ} \mathrm{C}$ & $-2^{\circ} \mathrm{C}$ & $15-18 \mathrm{C}$ & $350-1200$ \\
\hline saligna & $0-90$ & $26-33^{\circ} \mathrm{C}$ & $7-10^{\circ} \mathrm{C}$ & $0^{\circ} \mathrm{C}$ & $15-21^{\circ} \mathrm{C}$ & $600-900$ \\
\hline stolonifera & $5-300$ & $27-30^{\circ} \mathrm{C}$ & $6-8 \mathrm{C}$ & $-4 \mathrm{C}$ & $15-18^{\circ} \mathrm{C}$ & $800-1200$ \\
\hline "Cantabilling $^{*}$ & \pm 300 & $36 \mathrm{C}$ & $9 \mathrm{C}$ & $0^{\circ}$ & $18-21^{\circ} \mathrm{C}$ & \pm 500 \\
\hline
\end{tabular}

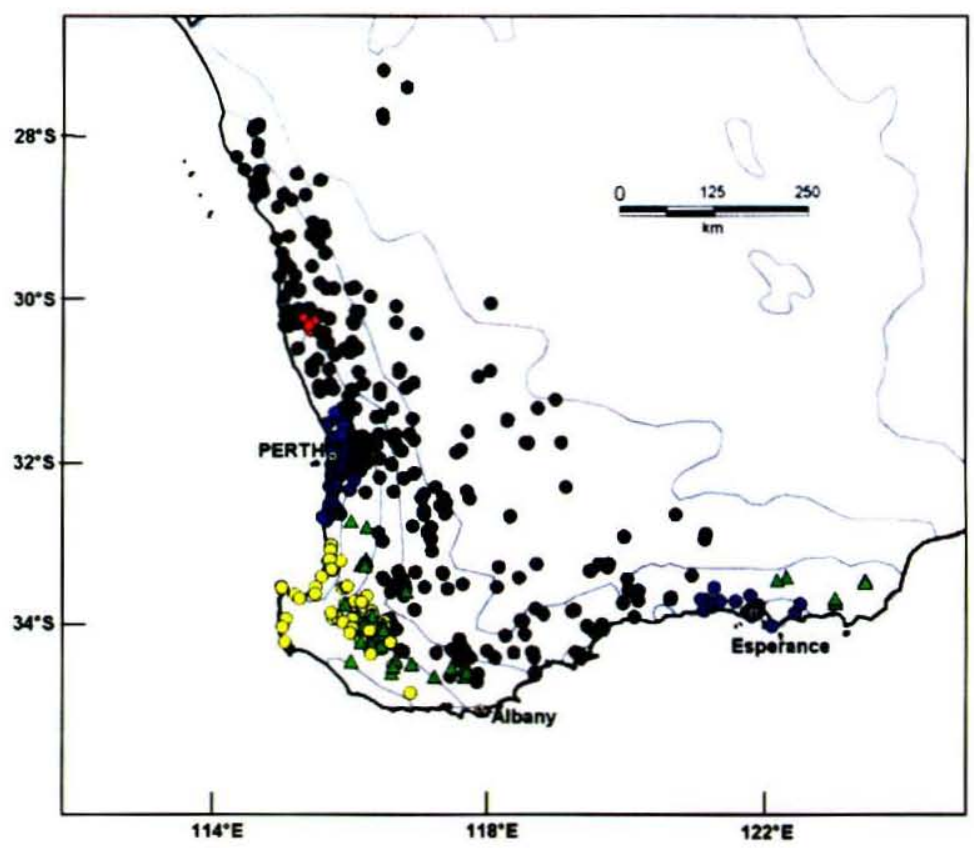

subsp. lindleyi subsp. pruinescens subsp. saligna black dot green triangle blue dot subsp. stonolifera yellow dot subsp. "Cantabilling" red diamond (rainfall isohyets approximate)

Figure 1

NATURAL DISTRIBUTION OF THE SUBSPECIES 
Subsp. lindleyi: natural stands of this taxon are the most widely dispersed, extending across the $250-650 \mathrm{~mm}$ rainfall zone in the wheat cropping area of south west Western Australia. It is displaced by its sister taxa (saligna, pruinescens and stolonifera) in the wetter south western extent of its range. Subsp. lindleyi extends the furthest inland where the hottest and driest conditions prevail. The habitat of subsp. lindleyi includes the base of granite rock outcrops, along seasonal creeks and rivers and on the fringes of salt lakes.

Subsp. pruinescens: this taxon has a widely disjunct distribution in southwest Western Australia where it occurs in two main regions separated by a distance of about $400 \mathrm{~km}$. Its western occurrences are mainly in the forested $700-1000$ $\mathrm{mm}$ mean annual rainfall zone, while the eastern disjunction is in a 350-650 mean rainfall zone near Esperance. Subsp. pruinescens is sympatric and forms hybrids with subsp. stolonifera in some higher rainfall areas of its distribution. The habitat of subsp. pruinescens is in proximity to diffuse drainage flats, rivers, seasonal creeks, swamps and lakes, except in the Esperance region, where it occurs near the base of granite rock outcrops.

Subsp. saligna: like subsp. pruinescens, natural populations of subsp. saligna also have a widely disjunct distribution in southwest Western Australia. They are restricted to coastal and subcoastal areas on the Swan Coastal Plain near Perth and to coastal and subcoastal sand plains in the Esperance region, about $600 \mathrm{~km}$ south east of Perth. The habitat of subspecies saligna is near swamps and seasonal creeks, on floodplains, along riverbanks and estuaries, near freshwater lakes, sand dune swales and the leeward side of coastal dunes.

Based on observations from a recent field trip to Región de Coquimbo, subsp. saligna is seemingly absent from any plantings in this region. This should be a cause for concern among local growers as based on observations from both natural populations and from cultivated stands, subsp. saligna produces the most biomass of the five subspecies and appears the fastest growing. Like subsp. pruinescens, it also has good coppicing ability, based on observations from natural stands.

Subsp. stolonifera: this taxon has the most south westerly distribution in the forested $800-1000 \mathrm{~mm}$ mean annual rainfall zone of south west Western Australia. Its habitat is also along watercourses, near swampy or low lying areas, along roadsides and on coastal plains and sand dunes. Populations near watercourses sometimes extend upslope to nearby low hills. As its epithet suggests, subsp. stolonifera has a propensity for aggressive root suckering. But despite its aggressive root sucking ability its coppicing ability appears to be weak, based on observations from natural stands.

Like subsp. saligna, subsp. stolonifera does not yet appear to have been cultivated in Región de Coquimbo. Based on observations from natural stands it appears to have poor coppicing ability, which could limit the potential of this subspecies, but this needs to be confirmed in coppicing trials. 
Subsp. "Cantabilling": is currently only known from a relatively restricted area an agricultural region north of Perth. It appears to be a short-lived taxon (only a 2-3 year life-span) and develops a spindly habit with very low levels of biomass.

This subspecies has limited potential for biomass production in Chile. Further information on its status will be presented in McDonald and Maslin (in prep.).

Despite this preference for water-gaining sites in their natural habitat outlined above, the adaptability of these subspecies to wide range of recharge sites has been demonstrated by their use and spread as an exotic in many parts of the world. Subsp. saligna, and to a less extent subsp. lindleyi, have become naturalised in parts of eastern Australia (south-eastern Queensland, coastal New South Wales, Victoria, Tasmania and South Australia). Plantings in numerous countries overseas, where they were introduced for site remediation, firewood and as a source of stock fodder, are also certain to be attributable to these two subspecies, and also subsp. pruinescens in some areas. In some instances, they have become notorious weeds, e.g., subsp. lindleyi in South Africa.

\section{Morphology}

A combination of some key phyllode and inflorescence traits distinguish the newly recognised subspecies of $A$. saligna (Table 2). There are numerous other, often subtle morphological differences that differ among taxa (e.g. flower head colour, resting inflorescence bud size and shape). These are fully documented in McDonald and Maslin (in prep.).

As would be expected from its wide geographic distribution, subsp. lindleyi is the most morphologically variable of the subspecies. It exhibits high levels of morphological variation within and among populations. For example, populations in the north of its range have glossier phyllodes compared to other parts of its range. Variation in habit in this subspecies will be of particular concern for domestication programs wishing to assess potential levels of biomass production based on natural populations. Subsp. lindleyi ranges from being a low shrub, less than $2 \mathrm{~m}$ tall in many areas in the north of its range, to being an arborescent tree up to $8 \mathrm{~m}$ tall in occurrences near the base of granite rock outcrops in the south of its range. By contrast, the other four taxa do not tend to exhibit this wide range in within and among population variation. Variation in its coppicing ability and root suckering propensity is currently poorly understood.

A good example of differences in the general appearance of subsp. pruinescens and subsp. lindleyi, was demonstrated in an INFOR trial established in 1999 near Tongoy, in the northern part of Region de Coquimbo (Fig. 2). These were the only two subspecies represented in the Tongoy trial with subsp. lindleyi being well represented by 12 provenances, while subsp. pruinescens had only two provenances represented (Boyatup Hill, Lake Muir). 
Table 2

SOME OF THE MAIN MORPHOLOGICAL DIFFERENCES THAT DISTINGUISH THE NEWLY RECOGNISED SUBSPECIES OF A. saligna

\begin{tabular}{|c|c|c|c|}
\hline Taxon & Habit & Phyllodes & Inflorescences \\
\hline lindley' & $\begin{array}{l}\text { low or large shrub } 2-5 \mathrm{~m} \text { tall, or small tree } \\
\text { up to } 8 \mathrm{~m} \text { tall with } \mathrm{dbh} \text { to } \mathrm{c} .30 \mathrm{~cm} \text {; root } \\
\text { suckering variable among populations: } \\
\text { coppicing ability poor }\end{array}$ & $\begin{array}{l}\text { slightly shiny or } \\
\text { glossy phyllodes } \\
\text { at all phases }\end{array}$ & $\begin{array}{l}\text { mostly } 5 \text {-headed } \\
\text { racemes, flower heads } \\
1.2-1.3 \mathrm{~cm} \text { in diameter }\end{array}$ \\
\hline prumescens & $\begin{array}{l}\text { a single-stemmed, small tree, } 3-8 \mathrm{~m} \text { tall } \\
\text { with a dbh to } 35 \mathrm{~cm} \text { on oldest trees. with a } \\
\text { spreading crown of bluish foliage; root } \\
\text { suckering ability profuse in some } \\
\text { populations; coppicing ability usually good }\end{array}$ & $\begin{array}{l}\text { dull, lightly } \\
\text { pruinose phyllodes } \\
\text { at all phases }\end{array}$ & $\begin{array}{l}\text { 7-8-headed racemes. } \\
\text { flower heads } 1.4 \mathrm{~cm} \text { in } \\
\text { diameter }\end{array}$ \\
\hline saligna & $\begin{array}{l}\text { densely-foliaged, spreading shrub or small } \\
\text { tree to } 10 \mathrm{~m} \text { tall, with a dbh to } 40-50 \mathrm{~cm} \\
\text { on oldest trees, root suckering usually } \\
\text { absent: coppicing ability usually good }\end{array}$ & $\begin{array}{l}\text { adult phyllodes } \\
\text { have a distinctly long } \\
\text { attenuated base }\end{array}$ & $\begin{array}{l}\text { 7-8-headed racemes, } \\
\text { flower heads } 1.7-1.8 \\
\mathrm{~cm} \text { in diameter }\end{array}$ \\
\hline stolonifera & $\begin{array}{l}\text { shrub or small tree } 3-8(-10) \mathrm{m} \text { tall. with } \\
\text { a dbh to } 35 \mathrm{~cm} \text { on oldest trees, often } \\
\text { forming dense clumps derived from root } \\
\text { suckers; coppicing ability poor }\end{array}$ & $\begin{array}{l}\text { long. narrowly } \\
\text { oblong. green } \\
\text { adolescent phyllodes }\end{array}$ & $\begin{array}{l}\text { 5-headed racemes, } \\
\text { flower heads } 1.7-1.8 \\
\mathrm{~cm} \text { in diameter }\end{array}$ \\
\hline "Cantabulfing" & $\begin{array}{l}\text { short-lived shrub. } 1-2 \mathrm{~m} \text { tall; root } \\
\text { suckering absent: coppicıng ability } \\
\text { absent }\end{array}$ & $\begin{array}{l}\text { long. linear phyllodes } \\
\text { at all phases }\end{array}$ & $\begin{array}{l}\text { mostly } 7 \text {-headed } \\
\text { racemes. flower heads } \\
1.2-1.4 \mathrm{~cm} \text { in diameter }\end{array}$ \\
\hline
\end{tabular}
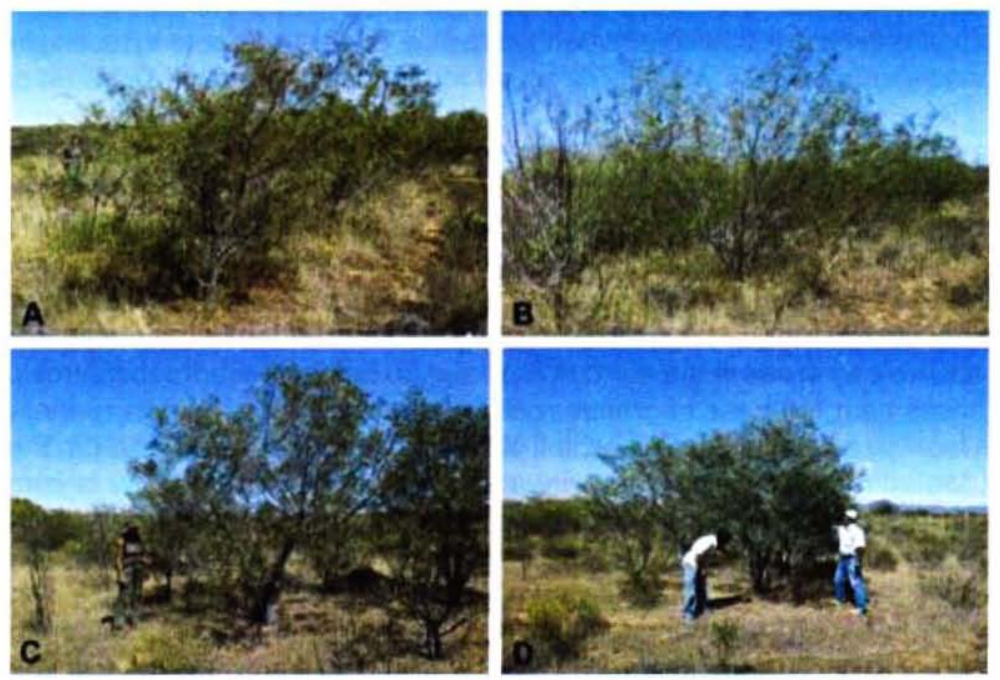

Figure 2

Acacia saligna subsp. lindleyi (A AND B TOP) AND A. saligna subsp. pruinescens (C AND D, BOTTOM) SHOWING DIFFERENCES IN THE GENERAL APPEARANCE OF THE TWO TAXA AT AGE 7 YEARS. THE TRIAL HAD 2 X 3 M SPACINGS AND WAS ESTABLISHED BY INFOR IN 1999 NEAR TONGOY, REGION DE COQUIMBO, CHILE. 


\section{AN OVERVIEW OF WORK UNDERWAY ON Acacia saligna IN WESTERN AUSTRALIA}

During the 1990s good progress was made in the domestication of mallee eucalypts (Bartle et al 2007). This led to the question of whether there might be other potentially useful crop species in the WA native flora (comprising 9979 species). A systematic assessment of the flora was undertaken based on both potential ease of domestication and on potential commercial values (Olsen et al 2004). This investigation identified the Acacia saligna group as highly prospective for domestication.

The first step in domestication was to clarify the taxonomic status of the species and this was the motivation for the work referred to above. With a clear understanding of the taxonomy it was possible to undertake systematic collection of seed from across the range of the four main subspecies. The collection consists of 20 families from each of 20 provenances (12 from subsp. lindleyi, 4 from subsp. saligna, 2 from subsp. pruinescens, and 2 from subsp. stolonifera). These collections were used to establish progeny experiments in winter 2006 at two widely separated locations across the range of natural occurrence of $A$. saligna. Each progeny experiment consists of nine replications of most of the 400 families in 4-tree plots to give a total planted population of more than 28,000 . Assessment of performance in the progeny experiments will commence in 2008.

Selections of various subspecies have been extensively planted in species comparison experiments across the south west of WA and several agronomic experiments have been established. The latter have a focus on water use which is an important aspect of performance both in terms of biomass production and in treating the major national problem of dryland salinity (National Land and Water Resources Audit 2001).

Initial assessment of product potential has shown significant variation in the fodder value of phyllodes (George et al 2007) and that the wood fraction has suitable properties for manufacture of panel products (Olsen et al 2004).

\section{THE SPECIES IN REGIÓN DE COQUIMBO}

Subsp. pruinescens is the most commonly cultivated subspecies of $A$. saligna in Región de Coquimbo of Chile. The performance of this taxon on seasonally dry, recharge sites in this region raises questions whether this taxon has a remarkable degree of adaptability to semiarid environments or if local environmental factors mediate conditions to facilitate its growth. The mean annual rainfall in Region de Coquimbo (ca $100-250 \mathrm{~mm}$ mean annual rainfall) is relatively low compared to the $300-1200 \mathrm{~mm}$ mean annual rainfall across the natural range of subsp. pruinescens in the south west of Australia. Subsp. pruinescens also favours relatively mesic habitats across its natural range being restricted to water-gaining sites near rivers, creeks and swamps. These factors suggest a priori it would poorly matched to the semi-arid conditions that prevail in Región de Coquimbo.

While detailed research is warranted to delineate the precise reasons that facilitate the successful growth of subsp. pruinescens in this region, some broad local environmental factors may help explain its success on recharge sites in Región de Coquimbo. The mean 
annual temperature range appears to be relatively mild. For example, $10-22^{\circ} \mathrm{C}$ was given for Coquimbo, in the northern part of Region de Coquimbo (Armesto and Vidiella 1993). On a seasonal basis this range appears to be remarkably uniform and benign compared to the ranges estimated for the subspecies of $A$. saligna in Table 1, and particularly for subsp. lindleyi. The annual rainfall in this region is supplemented by interception of moisture from coastal fogs, which occur over much of the year, particularly during spring and summer (Amigo and Ramirez 1998; Cereceda and Schemenauer 1991). Despite the prevalence of these fogs they do not play a role in groundwater recharge over large parts of the region (Sequeo et al. 2006). They do, however, play an important role in mediating evaporation rates, and humidity in the region rarely falls below $80 \%$ throughout the year (Armesto and Vidiella 1993). Water stress is further alleviated by groundwater aquifers being maintained by recharge from higher parts of the terrain during the dry season in this region (Sequeo et al. 2006). While empirical data on the extent of the root system of subsp. pruinescens is scant, it is considered to be relatively shallow. Based on the growth of subsp. pruinescens in Región de Coquimbo, its root system must be deep enough to have sufficient capacity to supplement annual rainfall with groundwater recharge during the dry season.

Apart from relatively low levels of evaporation, mild temperatures and favourable levels of groundwater, there are probably a suite of other subtle environmental factors that facilitate the general diversity of plant growth in

Región de Coquimbo, given that this a part of Chile that represents a global hotspot for plant biodiversity (Arroyo et al. 1999). Despite the high number of species present in the region, subsp. pruinescens is often grown where there is limited competition from other plants, most notably other shrub or tree species. This lack of below-ground competition for soil and water resources, plus the nitrogen-fixing ability of its root system, is also likely to play a role in the current successful growth of this subspecies in this region.

\section{Future Prospects for A. saligna in Región de Coquimbo}

Based on information presented here, prospects for the domestication of $A$. saligna in Región de Coquimbo can be improved by a more precise evaluation of its natural genetic resources. For example, given the success of subsp. pruinescens to date in this region, range-wide provenance trials are warranted. These should include seedlots that represent its disjunct distribution, particularly some of its isolated eastern occurrences, where limited gene flow among populations could have led to divergence in levels of adaptive variation. Similarly, range-wide provenance trials of subsp. saligna, which does not appear to have been introduced to this region to date, are warranted to compare its performance with subsp. pruinescens. A comparative assessment of the performance of provenances from the two main disjunct occurrences of subsp. saligna, would be particularly useful.

The adaptability of subsp. saligna to grow well outside the climate parameters shown in Table 1 is exemplified by its performance in Australia and parts of North Africa. Throughout much of south eastern Australia it has become a weed species, including subtropical summer rainfall areas where it was used to rehabilitate sand mining areas. In North African countries, it is grown in regions which receive a mean annual rainfall as low as $200 \mathrm{~mm}$ and on sandy free-draining sites that includes sand dunes (Le Houerou, 2000). Despite growing in such semi-arid conditions it was estimated to have the potential to produce up to $3000-5000 \mathrm{~kg}$ of 
dry matter forage per hectare. Sensitivity to cold rather than an intolerance of dry conditions was considered its main limitation in this region by Le Houerou. Areas above $800 \mathrm{~m}$ above sea level or areas where the mean minimum temperature of the coldest month is less than $3^{\circ} \mathrm{C}$, limit its survival. Based on these data, its performance in Región de Coquimbo could be equally impressive.

Differences in all growth traits among taxa under cultivation will need to be assessed to match domestication aims. For example, coppicing ability is an important genotypic trait that differs among subspecies, and possibly among populations within subspecies. Poor coppicing ability in any of the subspecies will eliminate their prospects as a coppice crop. Based on observations from natural stands, subsp. lindleyi appears to have relatively poor coppicing ability. With 12 provenances representing subsp. lindleyi in the INFOR Tongoy trial (Fig. 2), there is potential to comprehensively test the coppicing ability of this subspecies under cultivation. By contrast, the demonstrated coppicing propensity of subsp. pruinescens is clearly a major factor in its acceptance as crop plant in Región de Coquimbo at present.

The success of the performance of subsp. pruinescens has implications for climate matching other species with domestication potential to this region. Matching temperature parameters rather than rainfall data from natural stands may be a more reliable parameter to use as basis for selecting other species that have growth potential in Region de Coquimbo

\section{Potential for Collaboration}

The Future Farm Industries Co-operative Research Centre (FFI CRC) will direct the future course of domestication of Acacia saligna in WA. This will be part of a more substantial program of domestication of native species including mallee eucalypts and Atriplex nummularia and several other species. The proportion of research investment allocated to any species will be opportunistic, i.e. the species with the most promising results will attract the greatest share of research investment.

From the WA perspective, major targets for investment in Acacia saligna will be fodder value and agronomic performance. Assessment of fodder value (i.e. nutritive value) can involve expensive laboratory analysis. Costly analysis will limit the intensity of selection that could be applied in the progeny testing. Initial investigation has shown that Near Infra Red Spectrophotometry (NIR) may be adaptable to large volume low cost field based analysis. Another factor that may prove to be important in the domestication of Acacia saligna is tolerance of some endemic fungal diseases that appear to pose a serious threat to productivity. These two issues will be subject to intensive investigation as part of assessment of performance in the progeny experiments.

There are many other factors that must be investigated as part of the process of development of this species as a useful crop. The FFI CRC is keen to collaborate with Chilean interests in this work. 


\section{Acknowledgements}

Many thanks to INFOR staff, particularly Marta Abalos Romero, Santiago Barros, Juan Carlos Pinilla, Sandra Perret and also to Marcelo Cerda (CONFOR) who were extremely helpful and informative during a visit to Chile in January 2007 by MM. We are particularly grateful for the diligent efforts of Patricio Rojas Vergara (INFOR) who arranged the trip and was a most genial host during a field tour of Region de Coquimbo.

\section{REFERENCES}

Amigo, J. and Ramirez, C., 1998. A bioclimatic classification of Chile: woodland communities in the temperate zone. Plant Ecology. 139: 9-26

Aravena, R., Suzuki, O. and Pollastri, A., 1989. Coastal fog and its relation to groundwater in the IV Region of northern Chile. Chemical Geology. 79:83 \pm 91

Armesto, J.J. and Vidiella, P.E., 1993.'Plant life-forms and biogeographic relations of the flora of Lagunillas $\left(30^{\circ} \mathrm{S}\right)$ in the fog-free pacific coastal desert. Annals of the Missouri Botanical Garden. 80: 499-511.

Arroyo, M.T.K., Rozzi, R., Simonetti, J.A., Marquet, P. \& Salaberry, M., 1999. Central Chile. Hotspots: Earth's Biologically Richest and Most Endangered Terrestrial Ecoregions (ed. by R.A. Mittermeier, N. Myers, P.R. Ghil and C.G. Mittermeier), pp. 161-171. Conservation International and Agrupación Sierra Madre, Monterrey.

Bartle, J.R, Olsen, G., Cooper, D. and Hobbs, T.J., 2007. Scale of biomass production from new woody crops for salinity control in dryland agriculture in Australia. International Journal of Global Energy Issues: 27/2:115-137

Cereceda, P. and Schemenauer, R.S., 1991. The occurrence of fog in Chile. Journal of Applied Meteorology. 30:1097 \pm 1105

George, N.,, Byrne, M., Maslin, B.R. and Yan, G., 2006. Genetic differentiation among morphological variants of Acacia saligna (Mimosaceae). Tree Genetics and Genomes. 2: 109-119.

George, N., Henry, D.A, Yan, G. and Byrne, M. (in review) Variability in feed quality between populations of Acacia saligna and its correlation with genetic variation - implications for domestication. Animal Feed Science Technology.

Hobbs, T.J, Bennell, M, Huxtable, D., Bartle, J., Neumann, C., George, N. and O'Sullivan, W., 2006. 'FloraSearch Agroforestry Species and Regional Industries: Low rainfall farm forestry options for southern Australia.' A report for the Joint Venture Agroforestry Program and CRC for Plant-based Management of Dryland Salinity. RIRDC Publication No 06/

Maslin, B.R. and McDonald, M.W., 2004. AcaciaSearch. Evaluation of Acacia as a woody crop option for southern Australia. Report to the Rural Industries research and Development Corporation. Publication No. 03/017. Canberra, pp. 263.

McDonald, M.W. and Maslin, B.R. (in prep.). Infraspecific Variation in Acacia saligna (Labill.) H. Wendl. (Leguminosae: Mimosoideae). Manuscript prepared for submission to Australian Systematic Botany.

National Land and Water Resources Audit, 2001. Australian dryland salinity assessment 2000. Extent, 
impacts, processes, monitoring and management options. National Land and Water Resources Audit, Canberra, Australian Capital Territory. 129 p.

Olsen, G., Cooper, D. J., Huxtable, D., Carslake, J. and Bartle, J.R., 2004. Search Project Final Report. NHT Project 973849 - Developing Multiple Purpose Species for Large Scale Revegetation, CALM Kensington, Western Australia.

Squeo, F.A., Aravena, R., Aguirre, E., Pollastri, A., Jonquera, C.B. and Ehleringer, J.R., 2006. Groundwater dynamics in a coastal aquifer in north-central Chile: Implications for groundwater recharge in an arid ecosystem. Journal of Arid Environments. 67: 240-254 
